\title{
Dominant determinant characteristics of innovative behavior of new entrepreneur candidates
}

\author{
Iffah Budiningsih $^{\mathrm{a}^{*}}$, Heri Sukamto ${ }^{\mathrm{a}}$ and Sari Mujiani ${ }^{\mathrm{a}}$
}

${ }^{a}$ As-Syafi'iyah Islamic University, Jakarta, Indonesia

\section{H R O N I C L E}

Article history:

Received: November 22, 2020

Received in revised format:

December 292020

Accepted: January 28, 2021

Available online:

January 28, 2021

Keywords:

Creativity

Technology literacy

Risk-taking behavior

Innovative behavior

\section{A B S T R A C T}

In the global competition era and in Covid 19 pandemic period, the innovative competence of emerging entrepreneurs relies on the positive characters they should have. The present study was aimed to formulate a reinforcement model of innovative behavior through the identification of dominant determinant factors. The study employed survey methods and involved variables of innovative behavior $(\mathrm{Y})$, creativity $\left(\mathrm{X}_{1}\right)$, technology literacy $\left(\mathrm{X}_{2}\right)$, and risk-taking behavior $\left(\mathrm{X}_{3}\right)$. The respondents were 86 final year students of Faculty of Business Economics (emerging entrepreneur candidates) as the samples, and the data were further analyzed by multiple regression. The creativity $\left(\mathrm{X}_{1}\right)$, technology literacy $\left(\mathrm{X}_{2}\right)$, and risk-taking behavior $\left(\mathrm{X}_{3}\right)$ contribute simultaneously at 45.70 percent to the development of innovative behavior $(\mathrm{Y})$; b) the applicable prediction model of innovative behavior is $\mathrm{Y}=1.171+0.622 \mathrm{X}_{1}+0.170 \mathrm{X}_{2}-0.080 \mathrm{X}_{3}$; meanwhile, the creativity yielded the most significant sensitivity in developing the innovative behavior variable compared to the technology literacy and risk-taking behavior variables; $c$ ) it is worth noting that risk-taking behavior is not among the contributing factors; in fact, this variable constrains an individual to be innovative (if it is too high); e) the variable of creativity is in line with innovation.

\section{Introduction}

The institution of education, particularly in an advanced level, bears a significant and undeniable role to the nurturing process of its young entrepreneur cadres. Genetically, the characteristics of entrepreneurship, albeit in a small portion, are innately embedded within an individual since one was born. That said, the entrepreneurship education provided in higher education institutes, one's social circle, and other formal-nonformal education aids the individual to polish one's entrepreneurship skills. Technology has made it possible for businesses to thrive in the current global market era; by virtue of technological advancements, the quickness, accuracy, or mass-processing of a business is assured. The surge of businesses amid the present era of technology has highlighted the demand of the characters of business competitiveness, such as innovative behavior, creativity, technology literacy, and risk-taking behavior. The empirical studies have shown that entrepreneurs have the ability to create new job opportunities. Entrepreneurs are seen as the driving forces of the economy; their contributions are apparent to promoting economic growth and eradicating unemployment. At present, the total numbers of entrepreneurs in Indonesia only compose up to 3.1 percent of the country's total population. The number is alarmingly low compared to other countries that generally have about 5.0 percent proportion of entrepreneurs. For instance, the United States has 12.0 percent of entrepreneurs in the country, while the proportion of entrepreneurs in China and Japan is 10.0 percent and 11.0 percent respectively. In Southeast Asia, 7.0 percent of all Singaporeans are entrepreneurs, while Malaysia and Thailand had 5.0 percent and 4.0 percent in consecutive order. Compared to the neigh-bour countries, Indonesia is lacking in new entrepreneurs; such a situation calls for a development model to promote and encourage the numbers of emerging entrepreneurs, particularly from

* Corresponding author. Tel.: +62-818130957

E-mail address: iffah budiningsih@uia.ac.id (I. Budiningsih) 
the educated young generations. Thus, the present study devotes itself to formulate the model of innovative behavior reinforcement; further, it also aims to investigate the positive characters that are determinant to the innovative behavior: creativity, technology literacy, and risk-taking behavior.

The ever-changing development of science and technology in the era of business competition contributes to a shift in a dynamic of business environment. Such a situation demands a business person to embed oneself of the innovative competence and responsiveness to the rapid progression of technology. Immediate and accurate response towards the dynamics require the business to have the ability to innovate. Regarding this, the innovative behavior is not naturally established within an entrepreneur; it has to be shaped and developed by intentional interventions or by encouraging factors. innovation is the establishment process of a commercial product by inventing, creating, or developing a new product/process (Ireland et al., 2011, p. 334). By this, innovation is seen as the key element of entrepreneurship; not only correlated with technological sophistication, but it also involves innovation in terms of efforts or breakthroughs. An individual is considered innovative once one can actualize all the following stages: a) knowledge stage: gathering and understanding knowledge and skills necessary for adopting innovation effectively; b) persuasion stage: being attracted to innovation, discussing new behaviors, accepting innovation, and practicing positive outlook on an innovation/invention; c) decision stage: seeking new knowledge/information regarding innovation, executing innovation trial; d) implementation stage: beginning to implement the innovation continuously; and e) confirmation stage: acknowledging the benefits of innovation, integrating innovation within one's work, and promoting innovation to others (Roggers, 1995, p. 190). Supporting the notion, there are five assessment dimensions of an individual's innovative behavior: a) exploration of opportunities: showing attention, acknowledging and collecting information regarding opportunities; b) focus toward positive changes: formulating ideas/solutions to change, categorizing opportunities, combining ideas and information; c) trial: trying new ideas/solutions; d) seeking for support, mobilizing resources, persuading, promoting, negotiating, taking risk; e) implementation: implementing, modifying, and habituating (Kleysen \& Street, 2001, p. 284-296). Innovative behavior as the way a person produces, introduces, and apply new concepts or solutions (technology); the newly-applied ideas should be of significance to the business; this is reflected from particular efforts, i.e., developing ideas, finding opportunities, organizing the ideas, gaining support and implementing the ideas (Fauziah et al., 2017, p. 34). Based on the above notions, the main principle of innovative behavior is the ability to create, introduce, and to apply new inventions (idea/solution/technology) that are considered as beneficial for the business; the efforts are indicated by a) looking for/developing new ideas; b) practicing positive outlook on new things; c) looking for opportunities (going through trial and error); d) promoting ideas; e) gaining support for new ideas; and f) implementing new ideas.

Creativity is central to human's life. So important is creativity that it drives one's effort to invent new concepts, products, and procedures that are applicable in practical realms based on the dynamics of the problems in the society. In line with that, creativity is the mental activity of human beings in correlation with one's interaction with the environment. The activity is conducted simultaneously and persistently to formulate new ideas, findings, and methods that yield benefits to the social circles and surroundings (Jamaris, 2015, p. 74). Creativity involves two processes, namely cognitive (thinking) process based on one's insight and conceptualizing the ideas into a concrete product or service. The formulation of new ideas, without the implementation, is regarded as mere unimaginative creativity. Ergo, creativity refers to the intentional effort of utilizing one's insights to create breakthroughs and solutions to cope with problems. The standard definition of creativity is 'originality' and 'effectiveness'. That said, a new invention that is original and unique is only deemed as creative provided that it is effective and useful (Runco \& Jaeger, 2012, p.92); the process of creativity must be original, meaningful, and useful. Rogers posits several factors contributing to the rise of an individual's creativity, namely internal factors (openness, internal locus of evaluation, and eagerness in experimenting) and external factor/environment (Munandar, 2011, p. 114). Further, Rogers points out that the external factor refers to the environment that provides 'psychological security' (i.e., accepting someone as they are, removing external evaluation, and maintaining empathy) and 'psychological freedom' (the freedom to express oneself). Meanwhile another definition of creativity is the ability to formulate new imaginative ideas into a concrete product/service; it is related to openness, staying true to one's identity, freedom of expression, ease of discovery of new ideas, high flexibility, eager for originality, and high elaboration capability (Budiningsih et al., 2018, p. 457). Henceforth, the present study establishes that creativity is the ability that reflects the principles of openness, fluency, flexibility, originality in thinking, and ability to elaborate/develop/enrich/ breakdown an idea.

In general, literacy is interpreted as the set of essential ability and skill in reading, writing, speaking, calculating, and solving problems at a particular extent within daily activities. In other words, literacy is closely associated with the skill in language or in understanding a new thing (or cognitive skills). In Merriam-Webster dictionary, literacy is defined as the literate ability or quality, in which it involves the capacity to read, write, recognize, and understand ideas visually. The term 'technology' does not only correlate with 'machine/mechanic, but it is also associated with 'scientific study on practical matters' to solve problems. At present, the interpretation of 'technology' broadens to the notion of a scientific study on the implementation of particular procedures to solve problems. Greenstein has explained that technology is the integral and inseparable part of life; therefore, technology literacy is deemed as a significant element of essential life skills (Amin, et al., 2019, p. 439). The positive indicators of technology literacy: a) staying up-to-date with the recent technological advancements, b) understanding the implementation and limitation of technology, c) actively trying to implement technology in completing tasks, and d) showing willingness to learn new technology (United Nations Competency Development, 2010). Technology literacy is the set of 
abilities in the form of science, critical thinking skills, and decision-making skills in utilizing technology properly; the abilities are particularly related to its implementation in education (Taher \& Abtaria, 201, p. 150). Judson classifies technology literacy into three stages: 1) learning technology as based on the functions, 2) understanding the use of technology, 3) understanding the systems working within the particular technology (Taher and Abtaria, 2017, p. 150). Referring to the notions as stated previously, the study interprets technology literacy as the ability to use technology in completing tasks. The skill is indicated by following points: a) staying up-to-date with the recent technological advancements, b) understanding the implementation and limitation of technology, c) actively trying to implement technology in completing tasks, and d) showing willingness to learn new technology.

In general context, the term 'risk' is used in the fields of management, business, environment, insurance, or other fields related to decision-making. In business/ entrepreneurship scope, it is associated with the willingness and courage to take risks. The risk-taking character of an entrepreneur is seen as the tendency of someone to take a firm action in opening/managing new business, despite that it requires hefty-amount of capitals with uncertain results. Risk is the combination of probability of an event with the consequence or result (Siahaan, 2007, p. 2); ergo, risk-taking behavior is the process of making decisions regarding the opportunity of an event with the consequences whether or not the decision made is successful or failed. Failure is normal for entrepreneurs. They always seek for opportunities and acknowledge that failures yield many lessons to reflect on. The factors that influence risk-taking behavior include: a) establish that success is determined by one's own abilities; b) maintain positive outlook; c) the need for power; d) need for achievement; e) seek sensational experiences; f) tend to be selfless; g) environmental influences (Rachmahana, 2002, p. 57-58). The courage to task risk is the active competence to chase for opportunity despite its risks and uncertainty (Hatta, 2014, p. 91). In addition to that, the emerging entrepreneurs often have stronger risk-taking behavior than senior entrepreneurs (Taneo, et al., 2013, p.5). On one hand, risk-taking behavior can hamper the innovative behavior if not followed by comprehensive analysis; what is worse, it can lead to the fall of the business. Therefore, it is concluded that risk-taking behavior is the active ability to seek for opportunities without worrying of the risks and uncertainties. The behavior is indicated by several points: a) self-belief that success is determined by one's own abilities; b) maintenance of positive outlook; c) the need for power; d) the need for achievement; e) eagerness of sensational experiences; and f) selflessness. As based on the rationale, the study aims to formulate the reinforcement model of innovative behavior through the identification of determinant positive characters: creativity, technology literacy, and risktaking behavior. The model is expected to reinforce such behavior for entrepreneur candidates prior to starting ones' business. The research therefore establishes the hypothesis that creativity, technology literacy, and risk-taking behavior simultaneously and significantly influence innovative behavior.

\section{Research Method}

The study employed survey methods to identify the influence of independent variables, viz., creativity $\left(\mathrm{X}_{1}\right)$, technology literacy $\left(\mathrm{X}_{2}\right)$, and risk-taking behavior $\left(\mathrm{X}_{3}\right)$ towards dependent variables (Innovative behavior $(\mathrm{Y})$ ). As the emerging entrepreneurs, the respondents were the final semester students of Faculty of Business Economics, Universitas Islam As-Syafi'iyah Jakarta. A total of 86 samples were obtained from the total covered population of 400 students by simple random sampling technique. The data were collected by questionnaire instrument by employing Likert scale with five answer options: strongly agree $=5$, agree $=4$, slightly disagree $=3$, disagree $=2$, and strongly disagree $=1$. The data were analyzed by descriptive statistical (mean) analysis, correlation analysis, and multiple regression analysis. Prior to regression analysis, several requirement-tests were conducted: normality test, heteroscedasticity test, autocorrelation test, and multicollinearity test.

\subsection{Variable and Indicator of Research}

The research variable involved innovative behavior $(\mathrm{Y})$ as the dependent variable, while the independent variables referred to creativity $\left(\mathrm{X}_{1}\right)$, technology literacy $\left(\mathrm{X}_{2}\right)$, and risk-taking behavior $\left(\mathrm{X}_{3}\right)$; the indicators of variable are presented in Table 1 .

\section{Table 1}

Variable and Indicator of Research

\begin{tabular}{|c|c|c|c|}
\hline Variable & Indicator & & \\
\hline $\begin{array}{l}\text { Innovative } \\
\text { behavior (Y) }\end{array}$ & $\begin{array}{l}\text { a. seeking for/learning new things (developing } \\
\text { ideas); } \\
\text { b. maintaining positive thinking on new matters; } \\
\text { c. looking for opportunities (courage of trial and } \\
\text { error); } \\
\text { d. promoting ideas; } \\
\text { e. gaining support for new ideas; } \\
\text { f. implementing new ideas. }\end{array}$ & $\begin{array}{l}\text { Technology } \\
\text { literacy }\left(\mathrm{X}_{2}\right)\end{array}$ & $\begin{array}{l}\text { a. staying up-to-date with technological advance- } \\
\text { ments; } \\
\text { b. understanding the application and limitation of } \\
\text { technology; } \\
\text { c. actively trying to implement technology in com- } \\
\text { pleting tasks; } \\
\text { showing willingness to learn new technology. }\end{array}$ \\
\hline Creativity $\left(\mathrm{X}_{1}\right)$ & $\begin{array}{l}\text { a. openness; } \\
\text { b. fluency; } \\
\text { c. flexibility; } \\
\text { d. originality of ideas; } \\
\text { e. ability to elaborate, develop, and enrich the } \\
\text { ideas. }\end{array}$ & $\begin{array}{l}\text { Risk-taking } \\
\text { behavior }\left(\mathrm{X}_{3}\right)\end{array}$ & $\begin{array}{l}\text { a. self-belief of success is determined of one's ability; } \\
\text { b. practice of positive emotions; } \\
\text { c. need for power; } \\
\text { d. need for achievement; } \\
\text { e. eagerness for sensational experience; } \\
\quad \text { f. selflessness }\end{array}$ \\
\hline
\end{tabular}




\section{Test of instrument validity and reliability}

The results of validity and reliability tests of each instrument is displayed as follows:

Table 2

Validity and Reliability Test Results of $\mathrm{Y}, \mathrm{X}_{1}, \mathrm{X}_{2}$ and $\mathrm{X}_{3}$ Variables

\begin{tabular}{|c|c|c|c|c|}
\hline Variable & Statement item Valid & r-count (Pearson) value & Reliability Coefficient & Description \\
\hline Innovative behavior (Y) & 13 & $0.386-0.729$ & 0.810 & Valid and Reliable \\
\hline Creativity $\left(\mathrm{X}_{1}\right)$ & 14 & $0.362-0.673$ & 0.799 & Valid and Reliable \\
\hline Technology literacy $\left(\mathrm{X}_{2}\right)$ & 13 & $0.368-0.734$ & 0.841 & Valid and Reliable \\
\hline Risk-taking behavior $\left(\mathrm{X}_{3}\right)$ & 14 & $0.462-0710$ & 0.762 & Valid and Reliable \\
\hline
\end{tabular}

\section{Result}

\subsection{Descriptive Analysis}

The descriptive analysis results on all four research variables encompass the central tendency and dispersion (i.e., mean, median, mode, standard error of the mean, standard of deviation, variant, range, minimum score, and maximum score). Provided in Table 3 below are the details of the data.

Table 3

Description of Data of $Y, X_{1}, X_{2}$, and $X_{3}$ Variable

\begin{tabular}{|c|c|c|c|c|}
\hline & Innovative behavior & Creativity & Technology Literacy & Risk-taker \\
\hline $\mathrm{N}$ & 86 & 86 & 86 & 86 \\
\hline Mean & 3.9258 & 3.8812 & 3.6664 & 3.5241 \\
\hline Std. Error of Mean & .02673 & .02633 & .02550 & .03030 \\
\hline Median & 3.9231 & 3.8571 & 3.6923 & 3.5714 \\
\hline Mode & 3.85 & 3.86 & 3.69 & 3.57 \\
\hline Std. Deviation & .24791 & .24417 & .23647 & .28097 \\
\hline Variance & .061 & .060 & .056 & .079 \\
\hline Range & 1.38 & 1.50 & 1.31 & 1.50 \\
\hline Minimum & 3.15 & 3.07 & 3.00 & 3.00 \\
\hline Maximum & 4.54 & 4.57 & 4.31 & 4.50 \\
\hline Sum & 337.62 & 333.79 & 315.31 & 303.07 \\
\hline
\end{tabular}

The references of mean score to describe the variable of innovative behavior $(\mathrm{Y})$, creativity $\left(\mathrm{X}_{1}\right)$, technology literacy $\left(\mathrm{X}_{2}\right)$, and risk-taking behavior $\left(\mathrm{X}_{3}\right)$ are represented using the following score ranges: score $\quad 5.0=$ very high; score $4.0=$ high; score 3.0 = moderate; score $2.0=$ low; score $1.0=$ poor. In conclusion, the above Table 3 signifies that the mean score of future entrepreneurs' innovative behavior got 3.9258, rounded off to 4 with the error of the mean at 0.02673 . This result clarifies that the innovative behavior of the new entrepreneurs is in the 'high' category; thus, they only need to preserve the behavior to reach the maximum score of 5. The mean score of the variable of creativity is $\mathbf{3 . 8 8 1 2}$, rounded off to 4.0 , with the error of mean 0.02633 . Simply put, the category of the creativity of the new entrepreneurs is 'high.' The mean score and the error of the mean of the variable of technology literacy get $\mathbf{3 . 6 6 6 4}$ and 0.02550 , respectively. Such a result confirms that the technology literacy of future entrepreneurs is in the 'high' category. Lastly, the mean score and the error of the mean of the variable of risk-taking behavior get 3.5241 and 0.03030 , respectively. In other words, the risk-taking behavior of the future entrepreneurs is in the 'high' category.

\subsection{Requirement Analysis Test}

Requirement analysis testing (involving normality, heteroscedasticity, auto-correlation, and multicollinearity test) was conducted before the multiple correlation regression analysis. In the present work, the condition of all four requirement analysis has been met. The data of the variable $\mathrm{Y}, \mathrm{X}_{1}, \mathrm{X}_{2}$, and $\mathrm{X}_{3}$ were normally distributed (all data were in the diagonal line). The variant of the data of variable $\mathrm{Y}$ against the variables $\mathrm{X}_{1}, \mathrm{X}_{2}$, and $\mathrm{X}_{3}$ does not follow an obvious pattern; this indicates no heteroscedasticity. Since the tolerance value of the variable of $\mathrm{X}_{1}, \mathrm{X}_{2}$, and $\mathrm{X}_{3}$ was around 1 or the VIF under 10 , there is no autocorrelation. The D-W value ranges from -2 to 2 , indicating that there is no multicollinearity. Conditions of all four analyses have been met, and thus the regression model of the analyses results is feasible.

\subsection{Correlational Analysis and Multiple Regression}

The results of multiple correlational analysis between innovative behavior $(\mathrm{Y})$ with creativity $\left(\mathrm{X}_{1}\right)$, technology literacy $\left(\mathrm{X}_{2}\right)$, and risk-taking behavior $\left(\mathrm{X}_{3}\right)$ revealed that the $\mathbf{R}$-value scored $\mathbf{0 . 6 7 6}$ (see Table 4). Such a result indicates that the variable Y simultaneously correlated with the other three variables; the correlation was 'positive' and quite 'significant.' The value of determinant coefficient $\left(\mathrm{R}^{2}\right)$ was $\mathbf{0 . 4 5 7}$, significant, since the value of sig. $\mathbf{F}<\mathbf{0 . 0 5}(\mathbf{0 . 0 0}<\mathbf{0 . 0 5})$. In other words, the variable of creativity $\left(\mathrm{X}_{1}\right)$, technology literacy $\left(\mathrm{X}_{2}\right)$, and risk-taking behavior $\left(\mathrm{X}_{3}\right)$ simultaneously contributed to innovative behavior (Y) by $45.7 \%$. The remaining $54.3 \%$ was other factors (external). Provided in Table 4 is the overall result of the analysis of multiple correlation analysis and determinant coefficient. 
Table 4

Correlational Coefficient \& Determinant Coefficient between $\mathrm{Y}$ with $\mathrm{X}_{1}, \mathrm{X}_{2}, \mathrm{X}_{3}$

\begin{tabular}{|c|c|c|c|c|c|c|c|c|c|c|}
\hline \multirow[b]{2}{*}{ Model } & \multirow[b]{2}{*}{$\mathbf{R}$} & \multirow{2}{*}{\multicolumn{2}{|c|}{$\begin{array}{cc} & \text { Adjusted } \\
& \mathbf{R} \\
\text { R Square } & \text { Square } \\
\end{array}$}} & \multirow[b]{2}{*}{$\begin{array}{c}\text { Std. Error of } \\
\text { the Estimate }\end{array}$} & \multirow[b]{2}{*}{ R Square Change } & \multicolumn{3}{|c|}{ Change Statistics } & \multirow[b]{2}{*}{$\begin{array}{l}\text { Sig. F } \\
\text { Change }\end{array}$} & \multirow[b]{2}{*}{$\begin{array}{r}\text { Durbin- } \\
\text { Watson }\end{array}$} \\
\hline & & & & & & F Change & df1 & df2 & & \\
\hline 1 & $0.676^{\mathrm{a}}$ & 0.457 & 0.437 & 0.18602 & 0.457 & 22.993 & 3 & & 0.000 & 1.627 \\
\hline
\end{tabular}

a. Predictors: (Constant), Creativity, Technology Literacy, Risk-Taker

b. Dependent Variable: Innovative behavior

The result of ANOVA regarding the correlation of creativity $\left(X_{1}\right)$, technology literacy $\left(X_{2}\right)$, and risk-taking behavior $\left(X_{3}\right)$ with innovative behavior (Y) is provided in Table 5 and Table 6.

Table 5

ANOVA Regression of $Y$ against $\mathrm{X}_{1}, \mathrm{X}_{2}$, and $\mathrm{X}_{3}$

\begin{tabular}{clccccc}
\hline & Model & Sum of Squares & df & Mean Square & F & Sig. \\
\hline \multirow{2}{*}{1} & Regression & 2.387 & 3 & .796 & $.000^{\mathrm{b}}$ \\
& Residual & 2.837 & 82 & .035 & \\
\cline { 2 - 7 } & Total & 5.224 & 85 & & \\
\hline
\end{tabular}

a. Dependent Variable: Innovative behavior

b. Predictors: (Constant), Creativity, Technology Literacy, Risk-Taker

Table 6

Coefficients Regression of $Y$ against $\mathrm{X}_{1}, \mathrm{X}_{2}$, and $\mathrm{X}_{3}$

\begin{tabular}{|c|c|c|c|c|c|c|c|c|}
\hline \multirow{2}{*}{\multicolumn{2}{|c|}{ Model }} & \multicolumn{2}{|c|}{ Unstandardized Coefficients } & \multirow{2}{*}{$\begin{array}{c}\text { Standardized Coefficients } \\
\text { Beta }\end{array}$} & \multirow[b]{2}{*}{$\mathbf{t}$} & \multirow[b]{2}{*}{ Sig. } & \multicolumn{2}{|c|}{ Collinearity Statistics } \\
\hline & & B & Std. Error & & & & Tolerance & VIF \\
\hline \multirow[t]{4}{*}{1} & (Constant) & 1.171 & .409 & - & 2.860 & .005 & & \\
\hline & Creativity & .622 & .090 & .613 & 6.905 & .000 & .842 & 1.188 \\
\hline & Technology Literacy & .170 & .095 & .163 & 1.789 & .077 & .803 & 1.246 \\
\hline & Risk-taker & -.080 & .075 & -.091 & -1.069 & .288 & .909 & 1.100 \\
\hline
\end{tabular}

The results of the multiple regression coefficients in Table 6 formulate a model of multiple linear regression model describing the correlation of the innovative behavior $(\mathrm{Y})$ with creativity $\left(\mathrm{X}_{1}\right)$, technology literacy $\left(\mathrm{X}_{2}\right)$, and risk-taking behavior $\left(\mathrm{X}_{3}\right)$ as shown below.

$$
Y=1.171+0.622 X_{1}+0.170 X_{2}-0.080 X_{3}
$$

The result of the significance test on regression constants is a $=1.171$, with the sig value of 0.005 (see Table 6 ), categorized 'significant' as the value of sig. $<0.05(0.005<0.05)$. In other words, the constants in that model significantly influence the stimulation of innovative behavior. The result of significance test on regression $X_{1}$ is $b=0.622$, with the sign value of 0.005 (see Table 6), categorized 'significant' as the value of $\operatorname{sig}<0.05(0.000<0.05)$. In other words, the $\mathrm{X}_{1}$ variable or creativity significantly influences the stimulation of innovative behavior among the new entrepreneurs (Y). The result of the significance test on regression $\mathrm{X}_{2}$ is $\mathrm{c}=0.170$, with the sign value of 0.077 (see Table 6), categorized 'not significant' as the value of sig. $<0.05(0.077>0.05)$. In other words, the $\mathrm{X}_{2}$ variable or technology literacy does not significantly influence the stimulation of innovative behavior among the new entrepreneurs $(Y)$. The result of the significance test on regression $\mathrm{X}_{3}$ is $\mathrm{d}$ $=0.080$, with the sig value of 0.005 (see Table 6), categorized 'not significant' as the value of sig. $>0.05(0.288>0.05)$. In other words, the $\mathrm{X}_{3}$ variable or risk-taking behavior has no significant influence on the stimulation of innovative behavior among the new entrepreneurs (Y). The variable of creativity has the influence sensitivity on the innovative behavior at 0.622 . By that, this variable has dominant influences on innovative behavior compared to technology literacy $\left(\mathrm{X}_{2}\right)$ or risk-taking behavior. On the contrary, the risk-taking behavior $\left(\mathrm{X}_{3}\right)$ becomes a constraint since its regression correlation value is negative $(-0.08)$, although it is not that significant) and has no impact on the innovative behavior. The result of significance test on the multiple regression analysis is $Y=1.171-\mathbf{0 . 6 2 2} X_{\mathbf{1}}+\mathbf{0 . 1 7 0} \mathbf{X}_{\mathbf{2}}+\mathbf{0 . 0 8 0} \mathbf{X}_{\mathbf{3}}$, categorized 'significant' as the value of sig, 0.00 $<0.05$ (see Table 5). Such a result also signifies that the model can be used to predict the innovative behavior of the new entrepreneurs using the data of variables $X_{1}, X_{2}$, and $X_{3}$ if all of the independent variables have been identified. The multiple linear regression model $Y=\mathbf{1 . 1 7 1}+\mathbf{0 . 6 2 2} X_{1}+\mathbf{0 . 1 7 0} X_{2}-\mathbf{0 . 0 8 0} X_{3}$ further clarifies that if the value of the variable of creativity $\left(\mathrm{X}_{1}\right)$, technology literacy $\left(\mathrm{X}_{2}\right)$, and risk-taking behavior $\left(\mathrm{X}_{3}\right)$ are all 0 , the innovative behavior of the new entrepreneurs will get 1.171 (score below 1 , from the range of 1 to 5 , means poor category). It turns out that creativity $(0.622)$ has the greatest sensitivity influence level on innovative behavior compared to technology literacy $(0.170)$. Interestingly, risk-taking behavior hinders the cultivation of innovative behavior among the new entrepreneurs $(-0.080)$.

\section{Discussion}

Based on the mean score, the innovative behavior of the new entrepreneurs scored high at $=3.9258$, rounded off to 4.0 . This result reveals that the future entrepreneurs (which, at the moment of writing, are studying at the Faculty of Business and 
Economics for their bachelor's) have the capability to contribute to the economic productivity of Indonesia in terms of the micro and small business (start-up). Likewise, 'creativity' (3.8812), 'technology literacy' (3.6664), and 'risk-taking behavior' (3.5241) of the future entrepreneurs are in the high category. All of these four characters are the main qualities that a person should have to be a professional entrepreneur in a competitive global business environment.

The multiple linear regression model $Y=\mathbf{1 . 1 7 1}+\mathbf{0 . 6 2 2} \mathrm{X}_{\mathbf{1}}+\mathbf{0 . 1 7 0} \mathrm{X}_{\mathbf{2}}-\mathbf{0 . 0 8 0} \mathrm{X}_{\mathbf{3}}$ reveals that the variable of creativity $\left(\mathrm{X}_{1}\right)$ is significantly influential on innovative behavior and technology literacy variable is not significant to influence the innovative behavior. It is worth noting that risk-taking behavior is not among the contributing factors; this variable constrains an individual to be innovative. Hal ini sejalan dengan kreativitas yang berkembang seiring dengan perkembangan inovasi, artinya tidak adanya inovasi adalah tidak adanya kreativitas. Sederhananya, kreativitas adalah kekuatan pendorong inovasi (Sokolova, 2015). In the same tune, add that creativity is a characteristic that significantly contributes to the cultivation of innovative behavior compared to intervention approaches through training on technology (Budiningsih, et al., 2020, p. 162).

In the present work, the 'technology literacy' and 'risk-taking behavior' have little to influence on the cultivation of innovative behavior. In fact, risk-taking behavior hinders a person from being innovative. The respondents of this research are all entrepreneur candidates who are still in their bachelor's study; thus, they are yet to use technology in operating their business. On that ground, technology has no significant impact on the cultivation of innovative behavior. This notion corresponds to the one seen in a study by Ahmad argue that define of technology literacy as the ability to effectively and efficiently take advantage of technology and information in various contexts, e.g., work environment, business, teaching or learning, and daily life (Faizah, et al., 2020, p.4008).

In this study, the risk-taking behavior has no significant effect on innovative behavior. This variable has a negative impact on innovative behavior (regression coefficient at -0.080). Simply put, the more risk-taking qualities a person has, the more likely the person to be less innovative. Such a notion suggests that beginner entrepreneurs should take into consideration (be careful) every decision they are going to make in business. This is because risk-taking behavior is an activity that may result in a risk for almost every person; and this is the reason why such a behavior might be the risk factor of anxiety, thus hampering a person to be innovative (Rachamahana, 2002, p. 55). The present study results are in line with the study by Winawod that reveals that business risks are insignificant to business performance, because business performance is determined by the innovation of a product (Sepang \& Tawas, 2018, p. 2916) [19]. In this present study, the innovative behavior is not determined by the risk-taking behavior, and thus it clarifies the notion that business performance is only determined by the innovative behavior.

\section{Conclusion}

This study concludes that: a) based on the mean score, the innovative behavior and the creativity of the new entrepreneurs scored high at 3.9258 and 3.8812, high category. The mean score (mean) of the variable of technology literacy and risk-taking behavior gets 3.6664 and 3.5241, respectively. Both variables are in a relatively high category. b) the variable of creativity, technology literacy, and risk-taking behavior simultaneously have a positive, significant correlation with innovative behavior (multiple correlation coefficient value $\mathbf{R}=\mathbf{0 . 6 7 6}$ ), and the value of the determinant coefficient $\left(\mathrm{R}^{2}\right)$ was $\mathbf{0 . 4 5 7}$, categorized as significant. In other words, the variable of creativity $\left(\mathrm{X}_{1}\right)$, technology literacy $\left(\mathrm{X}_{2}\right)$, and risk-taking behavior $\left(\mathrm{X}_{3}\right)$ simultaneously contributed to innovative behavior (Y) by $45.7 \%$. The remaining $54.3 \%$ was other factors (external). c) the multiple linear regression model $Y=1.171+\mathbf{0 . 6 2 2} X_{1}+\mathbf{0 . 1 7 0} \mathbf{X}_{2}-\mathbf{0 . 0 8 0} X_{3}$ is applicable for predicting the influence of innovative behavior and reveals that the variable of creativity $\left(\mathrm{X}_{1}\right)$ is significantly influential on innovative behavior compared to technology literacy and risk-taking behavior. d) technology literacy and risk-taking behavior are not insignificant (small effect) to the cultivation of innovative behavior of new entrepreneurs. e) it is worth noting that risk-taking behavior is not among the contributing factors; in fact, this variable constrains an individual to be innovative (if it is too high); f) creativity of a person grows along with the innovative behavior, meaning that the absence of innovation is the absence of creativity. In other words, creativity is a driving force of innovation.

\section{References}

Amin, M., Khalil, M., Lukiati, B. \& Kodama, Y. (2019). The Effectiveness of Bioinformatic Module Based on Problem-Based Learning Toward Technology Literation Skills of Biology Master Program Students. International Conference on the https://www.atlantis-press.com/proceedings/ticash19/125940661.

New York. United Nations, Human Resources Management. (2010). United Nations Competency Development - A Practical Guide. https://www.google.com/search?client=firefoxb\&q=un+competency+development+a+practical+guide.

Budiningsih, I., Soehari, T. D. \& Leonard J. (2018). Dominant Factors Influence The Behavior to Produce Innovatif Product. China-USA Business Review, 17(9), 457..

Budiningsih, I., Soehari, T. D. \& Hidayati, R. N. (2020). Technology Trining \& Creativity for Strengthening Employees Innovatove Behaviors. GATR Global Journal of Business and Social Scince Review, 8(3),162 - 169.

Faizah, H. \& Jufri, A.W. \& Setiadi, D. (2020). Technology Literation: The Effect on Quality of Learning in Elementary School of Lentera Hati Islamic Boarding School. Traektoriâ Nauki = Path of Science, 6(8), 4007 - 4013. 
Fauziah S., Budiningsih I., Djaelani, A., \& Ahmad. M. (2017). Dominan factors affecting the behavior of innovatove employees. Polish Journal of Manageen Studies (PJMS), 16(1), 34. doi:10.17512/pjms.2017.16.03.

Hatta, I. H. (2014). Analisis Pengaruh Inovasi, Pengambilan Resiko, Otonomi, Dan Reaksi Proaktif Terhadap Kapabilitas Pemasaran UKM Kuliner Daerah Di Jabotabek (Analysis of The Influence of Innovation, Risk Taking, Autonomy, and Proactive Reaction to The Marketing Capabilities of Regional Culinary SMEs In Jabotabek). Jurnal Manajemen Pemasaran. 8 (2), 91. doi: 10.9744/pemasaran.8.2.90-96.

Ireland, R. D, Hoskisson, R.E. \& Hitt, M.A. (2011). The Management of Strategy: Concept and Cases, Mason, OH:SouthWestern, Cengage Learning.

Jamaris, M. (2015). Orientasi Baru Dalam Psikologi Pendidikan (New Orientation in Educational Psychology). Bogor: Ghalia Indonesia.

Kleysen, R. F., \& Street, C. T. 2001. Toward A Multi-Dimensional Measure of Individual Innovative Behaviour. Journal of Intelectual Capital, 2(3), 284-296.

Munandar, U. (2011). Development of Talented Children Creativity. Jakarta: Rineka Cipta.

Rachmahana, R. S. (2002). Dorongan Mencari Sensasi Dan Perilaku Pengambilan Resiko Pada Mahasiswa (The Urge to Find Sensations and Risk-Taking Behaviors in Students). Jurnal Psikologika, VIII (14), 57-58.

Roggers, E. M. (1995). Diffusion of Innovations. Fourth Edition. New York: The Free Press.

Runco, M. A. \& Jaeger, C. J. (2012). The Standard Definition of Creativity. Creativity Research Journal . 4 (1), $92-96$. https://doi.org/10.1080/10400419.2012.650092.

Siahaan, H. (2007). Manajemen Resiko; Konsep, Kasus dan Implementasi (Risk Management; Concepts, Cases and Implementations). Jakarta: PT Elex Media Komputindo.

Sokolova, S. (2015). The Importance of Creativity and Innovation in Business.

Taher, M. \& Abtaria, Y. (2017). Efektifitas Pembelajaran Creative Problem Solving Berbasis Eksperimen Dalam Pembelajaran Fisika untuk Melatihkan Literasi Teknologi Siswa (Effectiveness of Creative Problem-Solving Learning Based on Experiments in Physics Learning to Train Student Technology Literacy). Jurnal Gravity, 3(2), 150.

Taneo, S. Y. M., Setiyati E.M. \& Stephanus, D. (2013). Innovation and Economic Behavior of China Ethnic Entrepreneurs in Improving Competitiveness of Small and Medium Scali Food Industry. Proceeding of 2013 ICOI The International Conference on Organizational Innovation. https://www.academia.edu/21102161/INNOVATION_ AND_ECONOMIC BEHAVIOR OF CHINESE ETHNIC ENTREPRENEURS IN IMPROVING COMPETITIVENESS OF SMALL AND MEDIUM SCALE FOOD INDUSTRY.

Winawod, N. $\bar{A}$., Sepang, J.L. \& Tawas, H.N. (2018). The Influence of Innovation and Courage to Take on Product Performance with The Intensity of Competition as a Moderating Variable. Journal EMBA, 6(4), 2908 - 2917. 
(C) 2021 by the authors; licensee Growing Science, Canada. This is an open access article distributed under the terms and conditions of the Creative Commons Attribution (CC-BY) license (http://creativecommons.org/licenses/by/4.0/). 